\title{
Effect of Rhizobium Inoculation and Supplementation with Phosphorus and Potassium on Growth and Total Leaf Chlorophyll (Chl) Content of Bush Bean Phaseolus vulgaris, L.
}

\author{
Abdulkadir Mfilinge, Kelvin Mtei, Patrick Ndakidemi* \\ Nelson Mandela African Institution of Science and Technology, Arusha, Tanzania \\ Email: "ndakidemipa@gmail.com
}

Received 3 October 2014; revised 23 October 2014; accepted 20 November 2014

Copyright (C) 2014 by authors and Scientific Research Publishing Inc.

This work is licensed under the Creative Commons Attribution International License (CC BY).

http://creativecommons.org/licenses/by/4.0/

(c) (7)

Open Access

\begin{abstract}
The study was conducted to investigate the effect of Rhizobium inoculation and supplementation of phosphorus and potassium on growth and total leaf chlorophyll content to the three released bush bean varieties in northern Tanzania. To achieve this aim, the glasshouse experiment was conducted at Nelson Mandela African Institution of Science and Technology while field experiment were carried out at Tanzania Coffee Research Institute, in Kilimanjaro, Tanzania between AprilJuly 2014. The experiment was laid out in factorial arrangement. Factor I comprised of three bush bean varieties. Factor II involved two inoculation treatments viz 1) inoculation with Rhizobium spp. and 2) without inoculation. Factor III included four fertilizer levels $\left(0 \mathrm{Kg} \cdot \mathrm{ha}^{-1} 20 \mathrm{Kg} \mathrm{K} \mathrm{ha}^{-1}, 30\right.$ $\mathrm{Kg} \mathrm{P} \mathrm{ha}^{-1}$ and $20 \mathrm{~kg} \cdot \mathrm{K}+30 \mathrm{Kg} \mathrm{P} \mathrm{ha}{ }^{-1}$ ). Both screen house and field experiments were replicated four times. Plant growth parameters (plant height $(\mathrm{cm})$, number leaves per plant, stem girth (mm)) were measured at 2,4 and 6 weaks after planting (WAP). The chlorophyll was extracted by using Dimethylsulphoxide (DMSO) and absorbance was determined at 645 and 663nm using UV/Visible spectrophotometer. Results showed that Rhizobium application significantly improved the number of leaves per plant, plant height, pant girth and total leaf chlorophyll content. Furthermore, compared with the zero treatment control, potassium fertilization significantly increased the number of leaves per plant, plant height, pant girth and total leaf chlorophyll content of the three varieties. In general, these parameters were significantly increased with phosphorus supplied at 30 $\mathrm{kg} / \mathrm{ha}$. The combination of these supplies at different levels resulted in significant interactions in some parameters and thus indicating need for these inputs in the study area.
\end{abstract}

\footnotetext{
${ }^{*}$ Corresponding author.
}

How to cite this paper: Mfilinge, A., Mtei, K. and Ndakidemi, P. (2014) Effect of Rhizobium Inoculation and Supplementation with Phosphorus and Potassium on Growth and Total Leaf Chlorophyll (Chl) Content of Bush Bean Phaseolus vulgaris, L. Agricultural Sciences, 5, 1413-1426. http://dx.doi.org/10.4236/as.2014.514152 


\section{Keywords}

\section{Legumes, Total Leaf Chlorophyll Content, Photosynthesis, Plant Height, Rhizobia, Stem Girth}

\section{Introduction}

Nitrogen is the critical limiting element for growth of most plants due to its unavailability [1] [2]. Bush beans need nitrogen more than any other nutrient since it is an important constituent of proteins, enzymes, chlorophyll, and growth regulators [3]. It is a major part of the chlorophyll molecules and plays a necessary role in photosynthesis and also is a major component of several vitamins [4] [5]. A commonly known alternative source of nitrogenous fertilizer to legumes is the well documented rhizobial inoculants [6]. Several studies have indicated the potential of rhizobial inoculants in photosynthesis and chlorophyll content of legumes [5] [7]-[12]. However, Ali et al. and Malik et al. [13] [14] studies on Mungbean (Vigna radiata L.) and soybean (Glycine max L.) respectively found that Rhizobium inoculant significantly affected legume growth.

Phosphorus (P) is frequently one of the most limiting nutrients for plant growth in the tropics, and it is estimated that over $50 \%$ of common bean production in tropical soils is limited by phosphate deficiency [15] [16]. P is found in all living plant cell and resumes several key plant functions including energy transfer, photosynthesis, transformation of sugars and starches, nutrient movement within the plant [17] [18] nucleic acids, phospholipids, ATP, and it makes about $0.2 \%$ of plant's dry weight. Successful production systems based on legumes therefore, requires P inputs [19] either from soil reserves or from added fertilizer [20]. Optimum P supply is reported to stimulate the vegetative growth of common bean bush type cultivars by increasing shoot dry weight from 5.34 to $7.10 \mathrm{~g} \cdot$ plant $^{-1}$, root dry weight from 0.41 to $0.5 \mathrm{~g} \cdot$ plant $^{-1}$ [21]. The different behavior exhibited by shoot and root growth indicates that root growth is less sensitive to $\mathrm{P}$ deficiency than is shoot growth [22]. Supplementing legumes with $P$ has great potential for increasing legumes growth and yield [23] [24].

Potassium influences the process of photosynthesis at many levels, namely synthesis of ATP, activation of the enzymes involved in photosynthesis, $\mathrm{CO}_{2}$ uptake, and balance of the electric charges required for photophosphorylation in chloroplasts, and acting as the counter ion to light-induced $\mathrm{H}^{+}$flux across the thylakoid membranes [25]. Studies on cucumber cotyledons, cotton plants and Alfalfa plants have reported that adequate supply of potassium nutrient increase chlorophyll content [26]-[29]. Collins and Duke [30] also confirmed that K deficient in legumes is associated with low chlorophyll content. However, $\mathrm{K}$ has other important roles in major plant processes such as photosynthesis, respiration, osmoregulation, growth and yield of plant [31]-[33].

Beside of the studies above, there is little information about the effects of phosphorus, potassium and Rhizobium inoculant and their interaction on the chlorophyll formation in new released bush bean Phaseolus vulgaris L. in Tanzania. Therefore, it is important to establish and quantify the influence of phosphorus, potassium and Rhizobium inoculation on leaf chlorophyll content and growth in such legumes.

\section{Materials and Methods}

\subsection{Description of Location}

Field and pot experiments were conducted at two different locations from mid-March to late July 2013. A screen house experiment was conducted at Nelson Mandela African Institution of science and technology (NM-AIST) which is situated in an area which is $1250 \mathrm{~m}$ above the sea level in Arusha, Tanzania of latitude $3^{\circ} 38^{\prime} 33.00^{\prime \prime S}$ and longitude $36^{\circ} 38^{\prime} 06.29^{\prime \prime} \mathrm{E}$. The field experiment was conducted at the Tanzania Coffee Research Institute which is situated $1390 \mathrm{~m}$ above the sea level in Kilimanjaro region, Tanzania of latitude $3^{\circ} 14^{\prime} 44^{\prime \prime} \mathrm{S}$ and longitude $37^{\circ} 14^{\prime} 48^{\prime \prime} \mathrm{E}$. The field experiment was conducted in an area with bimodal rainfall pattern and mean annual rainfall of $1200 \mathrm{~mm}$.

\subsection{Experimental Design}

The experiment was laid out in factorial arrangement. Factor I comprised of three bush bean varieties. Factor II involved two inoculation treatments viz 1) inoculation with Rhizobium spp. and 2) without inoculation. Factor 
III included four fertilizer levels $\left(0 \mathrm{Kg} \cdot \mathrm{ha}^{-1}, 20 \mathrm{Kg} \mathrm{K} \mathrm{ha}^{-1}\right.$, $30 \mathrm{Kg} \mathrm{P} \mathrm{ha}{ }^{-1}$ and $\left.20 \mathrm{~kg} \cdot \mathrm{K}+30 \mathrm{Kg} \mathrm{P} \mathrm{ha}{ }^{-1}\right)$. Both screen house and field experiments were replicated four times.

\subsection{Field and Screen House Experiment}

The crop plant used for this experiment were 3 bush bean varieties recently released in mid-altitude zones in northern Tanzania namely: Lyamungo 90, Jesca and Selian 1997. They were supplied by the breeder from Selian Agricultural Research Institute (SARI), Arusha, Tanzania. The Rhizobium tropici (CIAT899) used was purchased from United Kingdom (UK). One kg of bean seeds was weighed and 10 gm of Rhizobium tropici inoculants was added and mixed according to manufacturer instruction so that all seeds are coated and are supplied with approximately $10^{9}$ cells/g seed. Then inoculated seeds were then sown immediately in a wet moist soil. The soil for screen house experiment was collected from the site where field experiment was conducted. The soil was packed into 4 kg pots. Four seeds were planted in each pot and later thinned to two after germination and uniform establishment.

The field was ploughed and harrowed by using tractor before planting. The plant spacing was $50 \mathrm{~cm}$ by $20 \mathrm{~cm}$ and the plot dimension was $4 \mathrm{~m}$ by $3 \mathrm{~m}$. In the field trial, four seeds were planted per hill and then thinned to two plants after germination and establishment. The plots were weeded twice. The first weeding was done two weeks after emergence and the second weeding was done just before flowering. Each plot had six rows. Both screen house and field experiments were conducted at the middle of March 2014, and closely monitored from this point until physiological maturity for field, and pod formation for screen house experiment.

\subsection{Growth Data Collection}

Data were collected from the four middle rows of each plot. The growth parameters were measured from 21 days after planting (DAP) to pod formation in both screen house and field experiment. Plant height was taken using measuring tape (from ground surface to the tip). Stem girth was measured using a vernier caliper. The number of leaves per plant was counted physically. Ten randomly selected representative plants from the four central rows in each plot for field experiment were to collect the growth parameters mentioned above, while two plant from each pot were used for screen house experiment.

\subsection{Chlorophyll Content Determination}

Extraction of chlorophyll by Dimethylsulphoxide (DMSO) was done as described by Hiscox and Israelstam (1979). The third leaf of each plant counted from the tip was collected from each pot for screen house and five leaf samples were taken from five randomly selected plants for field experiment. A hundred (100) $\mathrm{mg}$ of the middle portion of fresh leaf slices was placed in a $15 \mathrm{~mL}$ vial containing $7 \mathrm{~mL}$ DMSO and incubated at $44^{\circ} \mathrm{C}$ for $72 \mathrm{~h}$. After the incubation, the extract was diluted to $10 \mathrm{~mL}$ with DMSO. The DMSO technique extracts chlorophyll from shoot tissue without grinding or maceration (Hiscox and Israelstam, 1979). A $2 \mathrm{~mL}$ sample of chlorophyll extract was then transferred into curvets for absorbance determination. A spectrophotometer (UV/Visible Spectrophotometer) was used to determine absorbance at wavelengths 645 and $663 \mathrm{~nm}$, which was then used in the equation proposed by (Arnon, 1949) to determine total leaf chlorophyll content against DMSO blank, as shown below.

Chlorophyll total (Chlt $=20.2 \mathrm{D} 645+8.02 \mathrm{D} 663)$, where " $\mathrm{D}$ " is the density at the respective wavelengths which was obtained from Beckman Spectrophotometer.

\subsection{Statistical Analysis}

The data collected were analyzed using analysis of variance (ANOVA) in a factorial arrangement, with the computations being performed with the software program STATISTICA. The fisher least significance difference (L.S.D.) was used to compare treatment means at $\mathrm{p}=0.05$ level of significance (Steel and Torrie, 1980).

\section{Results}

\subsection{Effects of Rhizobia, K and P Fertilization on Plant Height of the 3 Bush Bean Varieties}

The results in Table 1 indicate that rhizobial inoculation significantly increased plant height $(\mathrm{cm})$ of all bush 
Table 1. Effect of rhizobium inoculation and supplementation of $\mathrm{P}$ and $\mathrm{K}$ on plant height of 3 bush bean varieties.

\begin{tabular}{|c|c|c|c|c|c|c|}
\hline \multirow{3}{*}{ Treatments } & \multicolumn{3}{|c|}{ Field condition } & \multirow{2}{*}{\multicolumn{3}{|c|}{$\begin{array}{l}\text { Screen house condition } \\
\text { Plant height (recorded) at }\end{array}$}} \\
\hline & \multicolumn{3}{|c|}{ Plant height (recorded) at } & & & \\
\hline & 2 WAP & 4 WAP & 6 WAP & 2 WAP & 4 WAP & 6 WAP \\
\hline \multicolumn{7}{|l|}{ Rhiz } \\
\hline- & $23.47 \pm 0.42 b$ & $26.37 \pm 0.40 \mathrm{~b}$ & $31.75 \pm 0.41 b$ & $18.40 \pm 0.40 \mathrm{~b}$ & $36.13 \pm 0.55 b$ & $39.65 \pm 0.60 \mathrm{~b}$ \\
\hline+ & $28.85 \pm 0.49 a$ & $29.13 \pm 0.30 \mathrm{a}$ & $36.65 \pm 0.47 a$ & $33.38 \pm 0.81 \mathrm{a}$ & $48.18 \pm 0.67 a$ & $52.10 \pm 0.60 \mathrm{a}$ \\
\hline \multicolumn{7}{|l|}{ Fert } \\
\hline Control & $24.21 \pm 0.84 \mathrm{c}$ & $26.33 \pm 0.45 b$ & $31.83 \pm 0.66 \mathrm{c}$ & $24.17 \pm 1.72 b$ & $39.08 \pm 1.43 \mathrm{~d}$ & $42.33 \pm 1.44 d$ \\
\hline $20 \mathrm{~K}$ & $25.67 \pm 0.85 b$ & $26.70 \pm 0.52 b$ & $33.29 \pm 0.68 b$ & $25.42 \pm 1.78 \mathrm{ab}$ & $41.25 \pm 1.47 \mathrm{c}$ & $44.92 \pm 1.50 \mathrm{c}$ \\
\hline 30P & $26.54 \pm 0.70 b$ & $27.80 \pm 0.45 a$ & $34.67 \pm 0.75 b$ & $26.13 \pm 1.78 a b$ & $43.13 \pm 1.42 b$ & $47.17 \pm 1.47 b$ \\
\hline $30 P+20 K$ & $28.25 \pm 0.80 \mathrm{a}$ & $30.17 \pm 0.51 \mathrm{a}$ & $37.00 \pm 0.75 a$ & $27.83 \pm 1.85 a$ & $45.17 \pm 1.51 \mathrm{a}$ & $49.08 \pm 1.46 \mathrm{a}$ \\
\hline \multicolumn{7}{|l|}{ Varieties } \\
\hline L.90 & $24.31 \pm 0.58 \mathrm{c}$ & $26.18 \pm 0.58 c$ & $33.97 \pm 0.76 b$ & $27.84 \pm 1.71 \mathrm{a}$ & $39.97 \pm 1.37 \mathrm{~b}$ & $44.47 \pm 1.50 \mathrm{~b}$ \\
\hline Jesca & $26.22 \pm 0.71 b$ & $27.59 \pm 0.28 b$ & $33.06 \pm 0.48 b$ & $25.59 \pm 1.46 b$ & $42.97 \pm 1.32 b$ & $46.28 \pm 1.38 b$ \\
\hline S.97 & $27.97 \pm 0.77 \mathrm{a}$ & $29.47 \pm 0.38 a$ & $35.56 \pm 0.73 a$ & $24.22 \pm 1.41 \mathrm{~b}$ & $43.53 \pm 1.16 \mathrm{a}$ & $46.88 \pm 1.07 \mathrm{a}$ \\
\hline \multicolumn{7}{|c|}{3 Way ANOVA (F stat) } \\
\hline Rhiz & $114.90^{* * *}$ & $253.7^{* * *}$ & $173.12^{* * *}$ & $301.08^{* * *}$ & $278.21^{* * *}$ & $355.47^{* * *}$ \\
\hline Fert & $11.36^{* * *}$ & $99.9^{* * *}$ & $34.87^{* * *}$ & $3.14^{*}$ & $12.92^{* *}$ & $19.41^{* * *}$ \\
\hline Varieties & $17.73^{* * *}$ & $121.2^{* * *}$ & $15.43^{* * *}$ & $6.00^{* *}$ & $9.35^{* *}$ & $4.80^{* * * *}$ \\
\hline Rhiz Fert & $0.46 \mathrm{~ns}$ & $1.4 \mathrm{~ns}$ & $0.21 \mathrm{~ns}$ & $0.10 \mathrm{~ns}$ & $0.05 \mathrm{~ns}$ & $0.07 \mathrm{~ns}$ \\
\hline Rhiz*Varieties & $1.03 \mathrm{~ns}$ & $65.1^{* * *}$ & 27.43ns & $2.95 \mathrm{~ns}$ & $2.07 \mathrm{~ns}$ & $6.76^{* *}$ \\
\hline Fert ${ }^{*}$ Varieties & $0.47 \mathrm{~ns}$ & $1.1 \mathrm{~ns}$ & $0.24 \mathrm{~ns}$ & $0.13 \mathrm{~ns}$ & $0.05 \mathrm{~ns}$ & $0.52 \mathrm{~ns}$ \\
\hline Rhiz*Fert ${ }^{*}$ Varieties & $1.33 \mathrm{~ns}$ & $1.9 \mathrm{~ns}$ & $0.38 \mathrm{~ns}$ & $0.03 \mathrm{~ns}$ & $0.11 \mathrm{~ns}$ & $0.09 \mathrm{~ns}$ \\
\hline
\end{tabular}

$+\mathrm{R}=$ With rhizobia; $-\mathrm{R}=$ Without rhizobia; $\mathrm{P}=$ Phosphorus; $\mathrm{K}=$ Potassium; $\mathrm{G}=$ Plant girth; $\mathrm{WAP}$ = Week after planting; L.90 = Lyamungo 1990; $\mathrm{S} .97=$ Selian 1997. Values presented are means $\pm \mathrm{SE} ;{ }^{* * * * * * * *}$ Significant at $\mathrm{p}=0.05, \mathrm{p} \leq 0.01, \mathrm{p} \leq 0.001$ respectively; ns $=$ not significant; $\mathrm{SE}=$ standard error. Means followed by dissimilar letter(s) in a column are significantly different from each other at $\mathrm{p}=0.05$ according to Fischer least significance difference.

bean varieties under this study in all reading both in the field and glass house experiment. The plant height for field experiment increased with rhizobial inoculation for the entire interval of the bush bean varieties growth. The plant height values recorded at 2, 4, and 6 weeks after planting (WAP), in the field experiment were 23\%, $10 \%$ and $15 \%$ respectively compared with the control. However, in the glass house the relative increase in plant height followed $81.4 \%, 12.1 \%$ and $31.4 \%$ for the value recorded at 2, 4, and 6 WAP respectively in the inoculated plots relative to the control.

Supplementing $\mathrm{K}$ and $\mathrm{P}$ at $20 \mathrm{~kg} / \mathrm{ha}$ and $30 \mathrm{~kg} / \mathrm{ha}$ respectively improved plant height both in field and glass house experiment. Result (Table 2) shows $\mathrm{K}$ and $\mathrm{P}$ application significantly improved plant height in all stages of legume growth for values recorded at 2, 4 and 6 WAP both the field and glass house experiment as compared to control. However, the combined effect of fertilizer gave better result than when $\mathrm{K}$ or $\mathrm{P}$ applied alone. For instance, for data collected at 2, 4 and 6 WAP, the combined effect of fertilizer increased plant height by $17 \%, 14 \%$ and $16 \%$ in the field experiment and $15 \%, 16 \%$ and $17 \%$ in the glass house experiment.

Result also indicates that the overall Varietal performance, Selian 1997 performed better in plant height in all stages of its growth followed by Jesca and Lyamungo. The performance of Selian 1997 for data recorded at 4 WAP in the field experiment and 6 WAP in the 6 WAP were significantly influenced by rhizobial inoculation.

In this study there was significant $(\mathrm{p}=0.001)$ interactive effect between Rhizobium inoculation and varieties on the plant height of bush bean varieties measured at forth weeks after planting in the field experiment and during the sixth week for measurements taken from the glass house experiment (Figure 4(a) \& Figure 4(b)) where Selian 1997 reached the maximum height of $29 \mathrm{~cm}$ tall relative to 26 and $27 \mathrm{~cm}$ tall exhibited by Lyamungo and Jesca respectively in the field experiment and also in screen house experiment Selian 1997 reached $47 \mathrm{~cm}$ tall relative to Lyamungo $44 \mathrm{~cm}$ and Jesca $46 \mathrm{~cm}$ relative to control. 
Table 2. Effect of rhizobium inoculation and of $\mathrm{P}$ and $\mathrm{K}$ fertilization on number of leaves, stem girth of 3 bush bean varieties.

\begin{tabular}{|c|c|c|c|c|c|c|c|c|}
\hline \multicolumn{5}{|c|}{ Field condition } & \multicolumn{4}{|c|}{ Screen house } \\
\hline \multicolumn{5}{|c|}{ Number of leaves plant girth (recorded) at } & \multicolumn{4}{|c|}{ Number of leaves plant girth (recorded) at } \\
\hline Treatments & $\begin{array}{c}\text { No. of Leaves } \\
4 \text { WAP }\end{array}$ & $\begin{array}{c}\text { No. of Leaves } \\
6 \text { WAP }\end{array}$ & $\begin{array}{l}\text { Plant G } \\
3 \text { WAP }\end{array}$ & $\begin{array}{l}\text { Plant G } \\
6 \text { WAP }\end{array}$ & $\begin{array}{l}\text { No. of } \\
\text { Leaves } \\
4 \text { WAP }\end{array}$ & $\begin{array}{l}\text { No. of } \\
\text { Leaves } \\
6 \text { WAP }\end{array}$ & $\begin{array}{l}\text { Plan G } \\
3 \text { WAP }\end{array}$ & $\begin{array}{l}\text { Plant G } \\
6 \text { WAP }\end{array}$ \\
\hline \multicolumn{9}{|l|}{ Rhiz } \\
\hline- & $19.93 \pm 0.51 b$ & $29.40 \pm 0.47 b$ & $3.90 \pm 0.05 b$ & $4.75 \pm 0.03 b$ & $7.50 \pm 0.22 b$ & $11.00 \pm 0.00 b$ & $4.25 \pm 0.05 b$ & $4.54 \pm 0.05 b$ \\
\hline+ & $21.04 \pm 0.33 a$ & $34.33 \pm 0.42 \mathrm{a}$ & $3.98 \pm 0.04 \mathrm{a}$ & $4.81 \pm 0.05 a$ & $8.00 \pm 0.00 \mathrm{a}$ & $11.67 \pm 0.14 \mathrm{a}$ & $4.50 \pm 0.06 a$ & $4.78 \pm 0.06$ \\
\hline \multicolumn{9}{|l|}{ Fert } \\
\hline Control & $19.88 \pm 0.54 b$ & $30.42 \pm 0.66 b$ & $3.72 \pm 0.05 c$ & $4.61 \pm 0.04 \mathrm{c}$ & $7.00 \pm 0.29 c$ & $11.08 \pm 0.06 b$ & $4.05 \pm 0.06 \mathrm{~d}$ & $4.35 \pm 0.07$ \\
\hline $20 \mathrm{~K}$ & $20.42 \pm 0.55 b$ & $31.25 \pm 0.80 b$ & $3.81 \pm 0.05 c$ & $4.67 \pm 0.05 c$ & $7.00 \pm 0.29 c$ & $11.33 \pm 0.13 b$ & $4.25 \pm 0.05 c$ & $4.52 \pm 0.06 c$ \\
\hline $30 \mathrm{P}$ & $21.50 \pm 0.70 b$ & $34.88 \pm 0.82 b$ & $4.01 \pm 0.05 b$ & $4.80 \pm 0.05 b$ & $7.38 \pm 0.25 b$ & $11.17 \pm 0.10 b$ & $4.47 \pm 0.06 b$ & $4.72 \pm 0.06 b$ \\
\hline $30 \mathrm{P}+20 \mathrm{~K}$ & $18.88 \pm 0.47 a$ & $33.41 \pm 0.81 \mathrm{a}$ & $4.21 \pm 0.05 a$ & $5.03 \pm 0.06 a$ & $7.63 \pm 0.21 \mathrm{a}$ & $11.75 \pm 0.24 \mathrm{a}$ & $4.73 \pm 0.06 a$ & $5.04 \pm 0.06$ \\
\hline \multicolumn{9}{|l|}{ Varieties } \\
\hline L.90 & $18.88 \pm 0.47 b$ & $31.25 \pm 0.47 b$ & $4.00 \pm 0.03 a$ & $4.56 \pm 0.04 b$ & $6.88 \pm 0.26 b$ & $11.38 \pm 0.14 b$ & $4.60 \pm 0.05 a$ & $4.92 \pm 0.06 a$ \\
\hline Jesca & $23.41 \pm 0.41 \mathrm{a}$ & $31.18 \pm 0.73 a$ & $3.97 \pm 0.07 \mathrm{ab}$ & $4.87 \pm 0.03 a$ & $8.00 \pm 0.00 \mathrm{a}$ & $11.41 \pm 0.16 a$ & $4.22 \pm 0.06 c$ & $4.47 \pm 0.06 c$ \\
\hline S.97 & $18.71 \pm 0.20 b$ & $32.47 \pm 0.76 a$ & $3.85 \pm 0.05 b$ & $4.89 \pm 0.05 a$ & $6.88 \pm 0.26 b$ & $11.22 \pm 0.10 \mathrm{c}$ & $4.31 \pm 0.07 b$ & $4.58 \pm 0.07 \mathrm{~b}$ \\
\hline \multicolumn{9}{|c|}{3 Way ANOVA (F stat) } \\
\hline Rhiz & $16.21^{* * *}$ & $116.94^{* * *}$ & $2.51 \mathrm{~ns}$ & $120.33^{* * *}$ & $123.43^{* * *}$ & $27.93^{* * *}$ & $37.79^{* * *}$ & $29.28^{* * *}$ \\
\hline Fert & $5.93^{* * *}$ & $19.88^{* * *}$ & $20.16^{* * *}$ & $91.49^{* * *}$ & $5.14^{* *}$ & $5.53^{* *}$ & $49.98^{* * *}$ & $44.25^{* * *}$ \\
\hline Variaties & $76.31^{* * *}$ & $11.56^{* * *}$ & $3.75^{*}$ & $1.85 \mathrm{~ns}$ & $30.86^{* * *}$ & $0.85 \mathrm{~ns}$ & $32.08^{* * *}$ & $36.68^{* * *}$ \\
\hline Rhiz Fert & $0.44 \mathrm{~ns}$ & $3.11^{*}$ & $0.41 \mathrm{~ns}$ & $0.16 n s$ & $5.14^{* *}$ & $5.53^{* *}$ & $0.42 \mathrm{~ns}$ & $0.03 \mathrm{~ns}$ \\
\hline Rhiz Varieties & $14.74^{* * *}$ & $1.09 \mathrm{~ns}$ & $0.49 \mathrm{~ns}$ & $9.28^{* * *}$ & $30.86^{* * *}$ & $0.85 n s$ & $2.09 \mathrm{~ns}$ & $4.55^{* *}$ \\
\hline Fert ${ }^{*}$ Varieties & $0.76 \mathrm{~ns}$ & $1.94 \mathrm{~ns}$ & $1.07 \mathrm{~ns}$ & $1.28 \mathrm{~ns}$ & $1.71 \mathrm{~ns}$ & $0.70 \mathrm{~ns}$ & $0.93 n s$ & $0.53 \mathrm{~ns}$ \\
\hline Rhiz $^{*}$ Fert ${ }^{*}$ Varieties & $0.42 \mathrm{~ns}$ & $0.33 n s$ & $0.17 \mathrm{~ns}$ & $0.69 \mathrm{~ns}$ & $1.71 \mathrm{~ns}$ & $0.70 \mathrm{~ns}$ & $0.20 \mathrm{~ns}$ & $0.47 \mathrm{~ns}$ \\
\hline
\end{tabular}

$+\mathrm{R}$ = with rhizobia; $-\mathrm{R}=$ Without rhizobia; $\mathrm{P}=$ Phosphorus; $\mathrm{K}=$ Potassium; $\mathrm{G}=$ Plant girth; WAP = Week after planting; L.90 = Lyamungo 1990; $\mathrm{S} .97=$ Selian 1997. Values presented are means $\pm \mathrm{SE} ;{ }^{* * * *, * * *}$ Significant at $\mathrm{p}=0.05, \mathrm{p} \leq 0.01, \mathrm{p} \leq 0.001$ respectively; ns $=$ not significant; SE $=$ standard error. Means followed by dissimilar letter(s) in a column are significantly different from each other at $\mathrm{p}=0.05$ according to Fischer least significance difference.

\subsection{Effects of Rhizobia, K and P Fertilization on the Number of Leaves of the 3 Bush Bean Varieties}

Rhizobia inoculation, fertilization ( $\mathrm{P}$ and $\mathrm{K}$ ) and the varieties tested had significant effect on the plant leaves assessed in this study (Table 2). For instance, Rhizobium inoculation significantly increased the number of leaves of the 3 bean varieties at 4 weeks after planting (WAP) by $6 \%$ and $7 \%$ both in the field experiments and screen house (Table 1) compared with the control treatments. However, for data collected 6WAP Rhizobium inoculation increased the number of leaves by $17 \%$ and $6 \%$ respectively relative to control.

In this study, supplying $\mathrm{K}$ and $\mathrm{P}$ alone could not significantly improve the number of leaves per plant for measurements taken 4 and 6 WAP. However, combined effect between $30 \mathrm{Kg}^{\circ} \mathrm{ha}^{-1}$ and $20 \mathrm{Kg} \cdot \mathrm{ha}^{-1}$ showed significant increase of leaves number as compared with all other treatments. Result indicate that variety Jesca performed better in the leaf number count followed by Selian 1997 and then Lyamungo 1990 both in field and glass house experiment.

This study showed significant $(\mathrm{p} \leq 0.001)$ interactive effect between Rhizobium inoculation and varieties on number of leaves both in the field and screen house experiment (Figure 5(a) \& Figure 5(b)). The significant effect was recorded at 4 WAP both in the screen house and field experiment. However, the Rhizobium inoculation also showed significant interactive effect with fertilizer both in the field and glass house experiment. In field experiment the interaction was significant $(\mathrm{p} \leq 0.05)$ on leaf number counted at $6 \mathrm{WAP}$, whereas in the glass house the interaction was significant $(\mathrm{p} \leq 0.01)$ on leaf number counted at 4 WAP and 6 WAP (Figures 1(a)-(c)). 


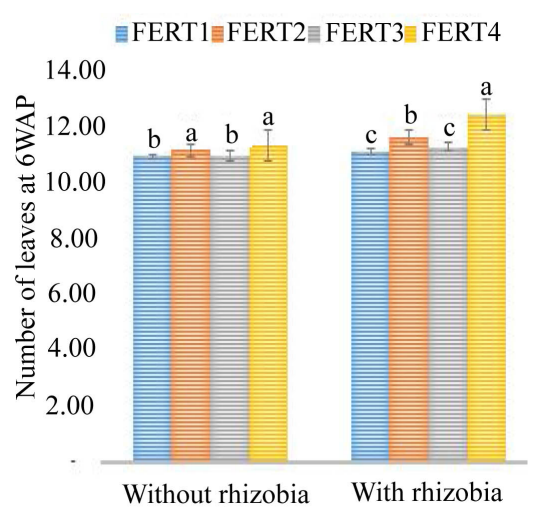

(a)

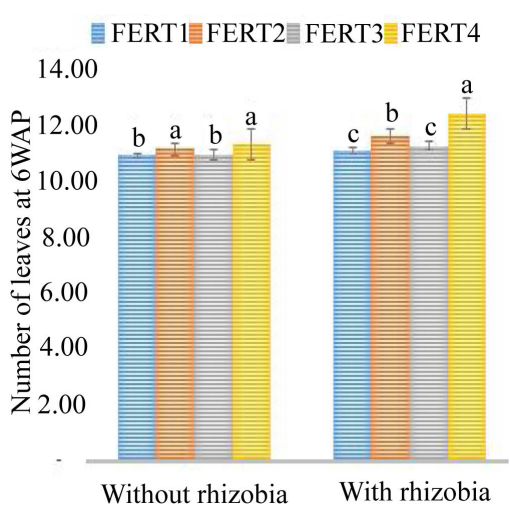

(b)

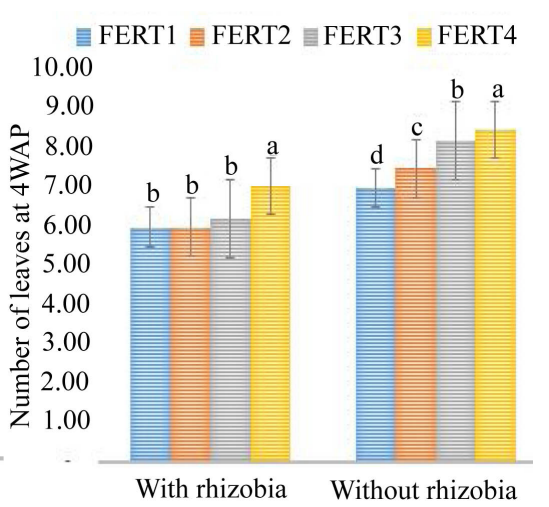

(c)

Figure 1. Interactive effects of rhizobia and fertilizer on number leaves in field and screen house experiment. L.90 = Lyamungo 1990: S.97 = Selian 1997. FERT1 = Zero fertilizer; FERT2 = 20 kg/ha K; FERT3 = 30 kg/ha P; FERT4 = Combination of $20 \mathrm{~kg} / \mathrm{ha} \mathrm{K}$ and $30 \mathrm{~kg} / \mathrm{ha} \mathrm{P}$. Bars followed by dissimilar letters are significantly different at $\mathrm{p}=0.05$ according to Fischer least significance difference (LSD). (a) Field experiment; (b) Scree house experiment; (c) Glass house experiment 4 WAP.

\subsection{Effects of Rhizobia, K and P Fertilization on Plant Girth of the 3 Bush Bean Varieties}

Result in Table 1 indicate that Rhizobium inoculation had significant effect to the plant girth recorded at 6 WAP in the field experiment and 3 WAP and 6 WAP in green house compared with control. Rhizobium inoculation increased plant girth by 1.3\% 6 WAP in field experiment and 5.1\% and $11.67 \%$ in green house for 3 WAP and 6 WAP respectively. In the field experiment, Rhizobium inoculation numerically, but not significantly increased plant girth at 3 WAP.

Application of phosphorus $30 \mathrm{~kg} \cdot \mathrm{ha}^{-1}$ generally increased plant girth both in field experiment and glasshouse experiment for all stages of legume growth. Plant girth, increased numerically but statistically insignificant by applying potassium at $20 \mathrm{~kg} / \mathrm{ha}$. Applying a combination of $30 \mathrm{~kg} \cdot \mathrm{ha}^{-1} \mathrm{P}$ and $20 \mathrm{~kg} \cdot \mathrm{ha}{ }^{-1} \mathrm{~K}$ improved plant girth both in field and glasshouse experiment. In the field experiment, the combination increased plant girth by $13 \%$ and 9\% in 3 WAP and 6 WAP, whereas, in glasshouse plant girth increased by $17 \%$ and $16 \%$ in 3 WAP and 6 WAP respectively compared with control. Generally, Lyamungo 1990 outperformed better than the other varieties both in the field and glass house experiment in all stages of their growth circle when girth of three varieties was to be compared. This was followed by Selian 1997 and the least was Jesca as shown in Table 2.

The interactive effect between Rhizobium inoculation and fertilizer was significant in both field and glass house experiment. However, the significant $(\mathrm{p} \leq 0.001)$ at the field level on plant girth was found on the 6 WAP. Result from the glass house also proved the interactive effect was significant $(\mathrm{p} \leq 0.01)$ on plant girth in glass house experiment at 6 WAP (Figure 2(a) \& Figure 2(b)).

\subsection{Effects of Rhizobia, Phosphorus and Potassium on the Total Leaf Chlorophyll of 3 Bush Bean Varieties}

The results in Table 3 indicated that the Rhizobium inoculation had positive effects on the total leaf chlorophyll content of bush bean varieties measured from three and six weeks after planting. Rhizobium inoculation significantly increased leaf chlorophyll content by $44 \%$ and 19\% in the field experiment for 3 WAP and 6 WAP respectively compared with un-inoculated plots. However, in the screen house the Rhizobium inoculation increased leaf chlorophyll content by $98 \%$ and $40 \%$ for data collected 3 and 6 week after planting compared with the control.

Supplementation of $\mathrm{K}$ at $20 \mathrm{~kg} / \mathrm{ha}$ and $\mathrm{P}$ at $30 \mathrm{~kg} / \mathrm{ha}$ all growth stages showed significant effect on the leaf chlorophyll content in both field and glass house experiment at 3, and 6 WAP. However, the combined effect of $\mathrm{K}$ and $\mathrm{P}$ indicated high total leaf chlorophyll content than when $\mathrm{K}$ or $\mathrm{P}$ were applied alone (Table 3). The combined effect of $20 \mathrm{~kg} \cdot \mathrm{ha}^{-1}$ and $30 \mathrm{~kg} / \mathrm{ha}$ increased the leaf chlorophyll content by $4 \%$ and $46 \%$ at $3 \mathrm{WAP}$ and 6 WAP relative to control in the field experiment and by $89 \%$ and $43 \%$ for data collected at 3 WAP and 6 WAP in the glass house experiment. 


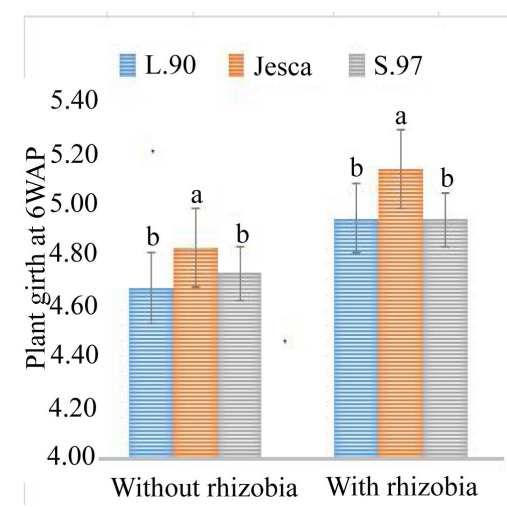

(a)

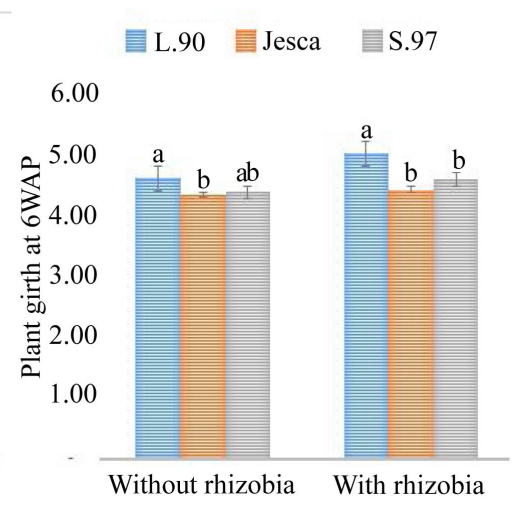

(b)

Figure 2. Interactive effects of rhizobia and varieties on plant girth in field and glasshouse experiment. L.90 = Lyamungo 1990: S.97 = Selian 1997. Bars followed by dissimilar letters are significantly different at $\mathrm{p}=0.05$ according to Fischer least significance difference (LSD). (a) Field experiment; (b) Glass house experiment.

Table 3. Effect of Rhizobium inoculation and supplementation of P and K on total chlorophyll content 3 bush bean varieties.

\begin{tabular}{|c|c|c|c|c|}
\hline \multicolumn{3}{|c|}{ Field condition } & \multicolumn{2}{|c|}{ Screen house } \\
\hline \multicolumn{3}{|c|}{ Total chlorophyll (recorded) at } & \multicolumn{2}{|c|}{ Total chlorophyll content (recorded) at } \\
\hline Treatment & 3 WAP & 6 WAP & 3 WAP & 6 WAP \\
\hline \multicolumn{5}{|l|}{ Rhiz } \\
\hline- & $4.07 \pm 0.09 b$ & $2.28 \pm 0.07 b$ & $33.11 \pm 1.21 b$ & $11.94 \pm 0.59 b$ \\
\hline+ & $5.84 \pm 0.21 \mathrm{a}$ & $2.72 \pm 0.08 \mathrm{a}$ & $44.34 \pm 1.29 \mathrm{a}$ & $23.61 \pm 1.03 a$ \\
\hline \multicolumn{5}{|l|}{ Fert } \\
\hline Control & $4.28 \pm 0.25 c$ & $2.00 \pm 0.11 c$ & $31.79 \pm 2.20 c$ & $12.26 \pm 1.07 \mathrm{~d}$ \\
\hline $20 \mathrm{~K}$ & $4.69 \pm 0.23 a b$ & $2.34 \pm 0.09 \mathrm{ab}$ & $36.34 \pm 1.84 b$ & $15.78 \pm 1.20 \mathrm{c}$ \\
\hline $30 \mathrm{P}$ & $4.99 \pm 0.21 b$ & $2.73 \pm 0.08 b$ & $41.28 \pm 1.66 b$ & $19.87 \pm 1.51 b$ \\
\hline $30 P+20 K$ & $5.85 \pm 0.37 a$ & $2.91 \pm 0.08 \mathrm{a}$ & $45.57 \pm 1.63 a$ & $23.20 \pm 1.95 a$ \\
\hline \multicolumn{5}{|l|}{ Varieties } \\
\hline S.90 & $5.18 \pm 0.18 a$ & $2.64 \pm 0.07 a$ & $38.30 \pm 1.31 b$ & $19.24 \pm 1.24 \mathrm{a}$ \\
\hline Jesca & $5.13 \pm 0.27 b$ & $2.46 \pm 0.13 b$ & $34.44 \pm 2.23 c$ & $19.12 \pm 1.63 b$ \\
\hline S.97 & $4.55 \pm 0.29 c$ & $2.40 \pm 0.10 b$ & $43.49 \pm 1.46 a$ & $17.97 \pm 1.47 \mathrm{c}$ \\
\hline \multicolumn{5}{|l|}{3 Way ANOVA (F stat) } \\
\hline Rhiz & $98.365^{* * *}$ & $57.900^{* * *}$ & $87.713^{* * *}$ & $280.687^{* * *}$ \\
\hline Fert & $13.874^{* * *}$ & $48.232^{* * *}$ & $24.647^{* * *}$ & $46.794^{* * *}$ \\
\hline Variaties & $5.062^{* *}$ & $6.742^{* *}$ & $18.971^{* * *}$ & $5.792^{* * *}$ \\
\hline Rhiz Fert & $1.415 \mathrm{~ns}$ & $2.112 \mathrm{~ns}$ & $0.136 n s$ & $6.040^{* * *}$ \\
\hline Rhiz Varieties & $3.865^{*}$ & $20.867^{* *}$ & $0.665 n s$ & $8.592^{* * *}$ \\
\hline Fert ${ }^{*}$ Varieties & $0.572 \mathrm{~ns}$ & $2.298^{*}$ & $1.542 \mathrm{~ns}$ & $1.223 \mathrm{~ns}$ \\
\hline Rhiz $^{*}$ Fert ${ }^{*}$ Varieties & $2.591^{*}$ & $1.431 \mathrm{~ns}$ & $1.234 \mathrm{~ns}$ & $0.747 \mathrm{~ns}$ \\
\hline
\end{tabular}

$+\mathrm{R}=$ With rhizobia; $-\mathrm{R}=$ Without rhizobia; $\mathrm{P}=$ Phosphorus; $\mathrm{K}=$ Potassium; $\mathrm{G}=$ Plant girth; WAP = Week after planting; L.90; Lyamungo 1990; S.97: Selian 1997. Values presented are means \pm SE; ${ }^{* * * * * * * *}$ Significant at $\mathrm{p}=0.05, \mathrm{p} \leq 0.01, \mathrm{p} \leq 0.001$ respectively; $\mathrm{ns}=\mathrm{Not}$ significant; SE $=$ Standard error. Means followed by dissimilar letter(s) in a column are significantly different from each other at $\mathrm{p}=0.05$ according to Fischer least significance difference (LSD).

This study indicated that the varietal response to total leaf chlorophyll content was significant both in the field and screen house experiment. However, when the 3 bean varieties were compared, Lyamungo 1990 scored higher amount of chlorophyll content followed by Jesca in the field experiment and Selian 1997 in the glass house experiment (Table 3). 
The results (Figure 6(a) \& Figure 6(b) and Figure 3(b)) show that there were significant interactive effect between Rhizobium and varieties both in the field and glasshouse experiment in total leaf chlorophyll content. For the field experiment, the interactions was significant for the total leaf chlorophyll content in bean varieties measured both in 3 WAP ( $\leq 0.05)$ and 6 WAP $(p \leq 0.01)$. However, in the glass house experiment, there was significant $(\mathrm{p} \leq 0.001)$ interactive between Rhizobium and varieties at 6 WAP. Generally Rhizobium inoculation supplied with bean varieties significantly gave higher amount of leaf chlorophyll content compared with the control.

The interaction between rhizobium $\times$ fertilizers $\times$ varieties was significant on the total leaf chlorophyll content only the field experiment. In the field experiment results showed the significant $(\mathrm{p} \leq 0.05)$ interactive effects on total leaf chlorophyll content between rhizobium $\times$ fertilizers $\times$ varieties measured at 3 WAP (Figure 8). The result generally indicated that Rhizobium combined with the application of fertilizer influenced growth parameters such as number of leaves and plant girth and eventually total leaf chlorophyll content in all bean varieties under the study.

\section{Discussion}

The study assessed the effect of Rhizobium inoculation with K and P fertilization on growth and total leaf chlorophyll content leaf to bush bean varieties (Phaseolus vulgaris, L.). The study showed that Rhizobium inoculation had positive effects on plant growth parameters (plant girth, height and number of leaves) for glass house and field experiment compared with un-inoculated treatment. Commonly, the un-inoculated controls showed relatively poor growth in all growth parameters measured. The increased plant height, stem girth, number of leaves per plant observed in the inoculated pots and plots might be due to symbiotic relationship between Rhizobum inoculation and root nodules of legumes which fix atmospheric nitrogen into a usable form used for the plant growth reflected in the measured parameters. It is well established that leguminous plants in partnership with Rhizobium have the ability to convert the atmospheric nitrogen into usable form [20] [34]-[36], which can be used by the plants. Similar to our results Tairo and Ndakidemi, Bambara and Ndakidemi, Nyoki and Ndakidemi, Ndakidemi and Semoka, Ravikumar [5] [11] [12] [20] [37] have reported significant improvement in various legumes growth in Tanzania when inoculated with specified legume inoculant.

Rhizobial inoculant however improved the total leaf chlorophyll content of all three bush bean varieties under the study. The study proved that rhizobial inoculation had significant effect to total leaf chlorophyll content to bush bean varieties both in the field and glass house experiment (Table 3). Inoculated treatments showed more dark green and found to be rich in leaf chlorophyll content as compared with un-inoculated treatments. In a study involving common bean by Bambara and Ndakidemi [38] in glasshouse and field experiment the leaf

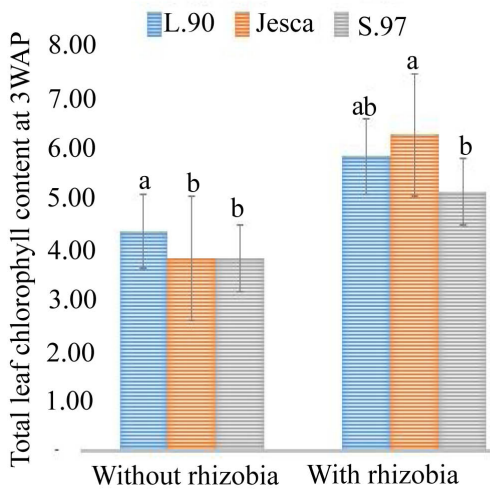

(a)

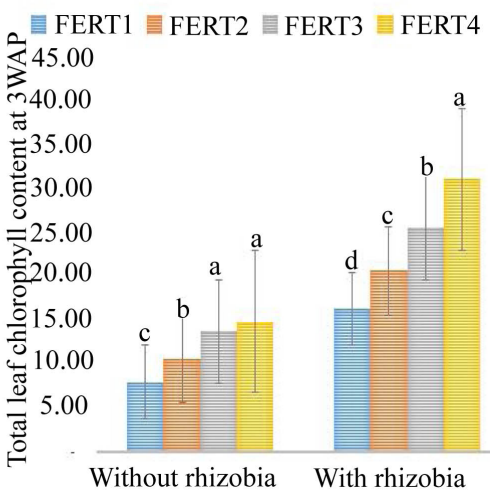

(b)

Figure 3. Interactive effects of (a) Rhizobia and varieties (b) Rhizobia and fertilizer on total leaf chlorophyll content recorded at 3 WAP and 6 WAP respectively. L.90 = Lyamungo 1990; S.97 = Selian 1997; FERT1 = Zero fertilizer; FERT2 = $20 \mathrm{~kg} / \mathrm{ha} \mathrm{K}$; FERT3 = $30 \mathrm{~kg} / \mathrm{ha} \mathrm{P}$; FERT4 = Combination of $20 \mathrm{~kg} / \mathrm{ha}$ $\mathrm{K}$ and $30 \mathrm{~kg} / \mathrm{ha} \mathrm{P}$. Bars followed by dissimilar letters are significantly different at $\mathrm{p}=0.05$ according to Fischer least significance difference (LSD). (a) Field experiment; (b) Glass house experiment. 
chlorophyll (Chl) content increased significantly with rhizobial inoculation. These improvements in inoculated treatments could be accredited to improved biological nitrogen fixation by rhizobial inoculants which increased nitrogen supply to the plants and subsequently increased total leaf chlophyll contents of the legumes. The results in the current study showed that Rhizobium inoculation increased leaf chlorophyll content by $19 \%$ and $44 \%$ in the field experiment and $40 \%$ and $98 \%$ in glasshouse experiment which is within the range of those reported earlier by Jairo and Ndakidemi, Nyoki and Ndakidemi, Bambara and Ndakidemi [5] [12] [38] in Phaseolus vulgaris bush type, Vigna ungiculata and Glycine max. The promising results attained from this study conclude that rhizobia inoculation may substitute the expensive inorganic $\mathrm{N}$ fertilizers in improving plant growth and chlorophyll synthesis.

In this study, phosphorus and potassium significantly improved all growth parameters assessed in the study both in the field experiment and glass house experiment. For instance, supplying $30 \mathrm{~kg} / \mathrm{ha}$ of P increased the height of bush bean varieties by $10 \%$ and $8 \%$ at the field and glass house experiment. Other parameters including plant girth and number of leaf were significantly improved by application of phosphorus $30 \mathrm{~kg} / \mathrm{ha}$ (Table 2). P-fertilizer application resulted in more vigorous plants with more intense green colour indicating higher chlorophyll content and greater photosynthetic ability [39]. This improvement could be due to functional importance of phosphorus in legume growth such as sugar and starch utilization, cell division and organization, photosynthesis use efficiency and formation of green pigment in plant which finally improve plant growth and chlorophyll synthesis. Such significant result in legumes has also been reported by Jairo and Ndakidemi, Nyoki and Ndakidemi, Berg and Lynd, Pacovsky, Kasturikrishna and Ahlawat [5] [12] [40]-[42].

Supplementing beans with $20 \mathrm{~kg} / \mathrm{ha}$ of K relatively improved plant height both in field and glass house experiment. The increase in plant height might be influenced by the role of potassium in photosynthesis, respiration, osmoregulation, growth and yield of plant [33]. The combination of $30 \mathrm{Kg} / \mathrm{ha}$ and $20 \mathrm{Kg} / \mathrm{ha}$ of P and $\mathrm{K}$ had significant effects in all parameters which were under observation. This may be accounted by the role played by phosphorus and potassium in legume nutrition, particularly in energy acquisition, storage and utilization [43]. Similar to our work, other related studies have reported on the effect of P and K on legume growth [20] [24] [44]-[50].

This study also showed significant interactive effects $(\mathrm{p}=0.001)$ between Rhizobium inoculation and varieties on plant height on the field and green house experiment (Figure 4(a) \& Figure 4(b)) and number of leaves (Figures 5(a) \& Figure 5(b)). For instance, whether inoculated with Rhizobium inoculation or un-inoculated, Selian 1997 significantly gave greater height compared with other variety in the field experiment. Generally, all 3 varieties recorded greater height when inoculated with Rhizobium inoculation both in field and glass house experiment (Figure 4(a) \& Figure 4(b)). However, the maximum number of leaves per plant was also observed where Rhizobium inoculation was supplied with varieties (Figure 5(b)).

A significant interactive effect was observed between Rhizobium inoculation and fertilizers on the number of leaves both in the field and screen house experiment (Figures 1(a)-(c)). Good results were recorded in Rhizo

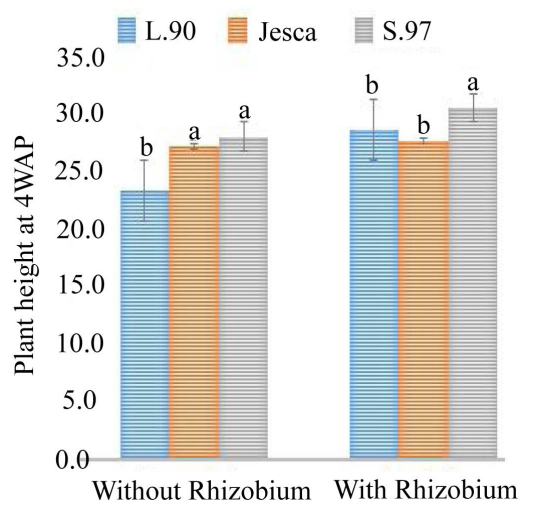

(a)

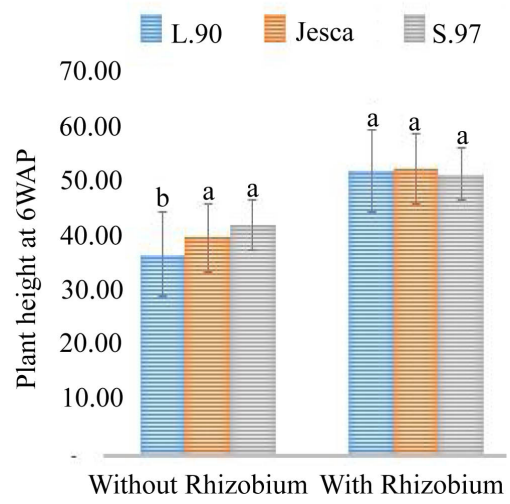

(b)

Figure 4. Interactive effect of rhizobia and variety on plant height in field and glass house experiment. L.90 = Lyamungo 1990; S.97 = Selian 1997. Bars followed by dissimilar letters are significantly different at $\mathrm{p}=0.05$ according to Fischer least significance difference (LSD). 


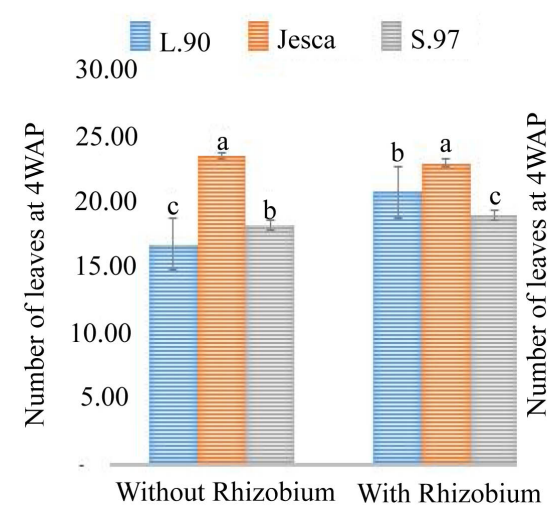

(a)

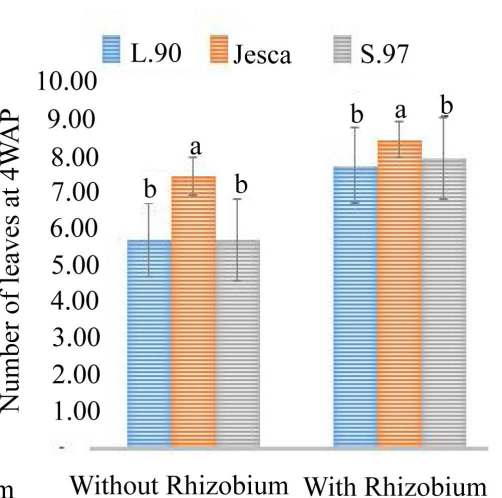

(b)

\begin{abstract}
Figure 5. Interactive of rhizobia inoculation and varieties on number of leaf in the glasshouse and field Experiment 2014. L.90 = Lyamungo1990; S.97 = Selian 1997. Bars followed by dissimilar letters are significantly different at $\mathrm{p}$ $=0.05$ according to Fischer least significance difference (LSD). (a) Field experiment; (b) Screen house experiment.
\end{abstract}

bium inoculated treatments in combination with the highest rate of fertilizer (Figures 1(a)-(c)), suggesting significant additive results by mixing these inputs. Similar to our findings, the role of rhizobia inoculation when supplement with inorganic fertilizer in legumes on leaf count have been reported by other researchers [5] [12] [14] [51] [52].

The interactive effect between Rhizobium inoculation and varieties on the plant girth was also observed (Figure 2(a) \& Figure 2(b)). However, the significant interaction $(\mathrm{p} \leq 0.001)$ Rhizobium inoculation and varieties on plant girth at the field level were noticeable on the 6 WAP. Improvements in inoculated treatments could be attributed to improved biological nitrogen fixation by rhizobial inoculants which increased nitrogen supply to the plants and consequently improved plant girth and other growth parameters [37] [53].

The results (Figure 6(a) \& Figure 6(b)) show that there were significant interactive ( $\mathrm{p} \leq 0.01$ ) effect between Rhizobium and varieties both in the field and glasshouse experiment. For the field experiment, the interaction was significant for the value of leaf chlorophyll content of three bush bean varieties measured in 6 WAP ( $\leq$ 0.01). All three bush bean varieties positively responded to increased total leaf chlorophyll content with Rhizobium inoculation suggesting the incumbent role of rhizobia in legume production. Interactive effects of fertilizer and varieties indicated significant interactive effects $(\mathrm{p} \leq 0.05)$ in leaf chlorophyll content (Figure 7). The three varieties yielded high amount of total leaf chlorophyll content when the combination of $20 \mathrm{~kg} / \mathrm{ha}$ of $\mathrm{K}$ and 30 $\mathrm{kg} / \mathrm{ha}$ of $\mathrm{P}$ were added to the soil indicating the importance of $\mathrm{P}$ and $\mathrm{K}$ in legume nutrition. Our result corresponds to the previous researchers who reported that adequate supply of potassium and phosphorus nutrient increase chlorophyll content in plants [27]-[29].

In the presence of all three treatments (Rhizobium, + P \& K fertilization and varieties), a significant interaction was observed on the total leaf chlorophyll content of Phaseolus vulgaris L. The greater leaf amount of chlorophyll content was observed in the highest rates of $\mathrm{P}$ and $\mathrm{K}$ in combination with Rhizobium inoculation in all 3 varieties under study (Figure 8). However, increased total leaf chlorophyll was recorded on the inoculated plots relative to un-inoculated plots. The result generally indicated that Rhizobium combined with the application of fertilizer influenced growth parameters such as number of leaves, plant height, plant girth and eventually total leaf chlorophyll content in all bean varieties in the field experiment. Other Studies by Shahid, Saleem, Khan, \& Anjum [18] [54]-[56] concluded that improved growth in these parameters suggest compatibility of rhizobia, fertilizer and varieties which in turn enhanced root formation, cell division and elongation, nodulation, $\mathrm{N}$-fixation and eventually plant growth with dark green color for plant food production.

\title{
5. Conclusion
}

Rhizobium inoculation and supplementation with phosphorus and potassium improved plant growth parameters (plant girth, height and number of leaves) and total leaf chlorophyll content of all three bush bean varieties tested in this study. Rhizobium inoculation alone had significant effect on all parameters under the study fol- 


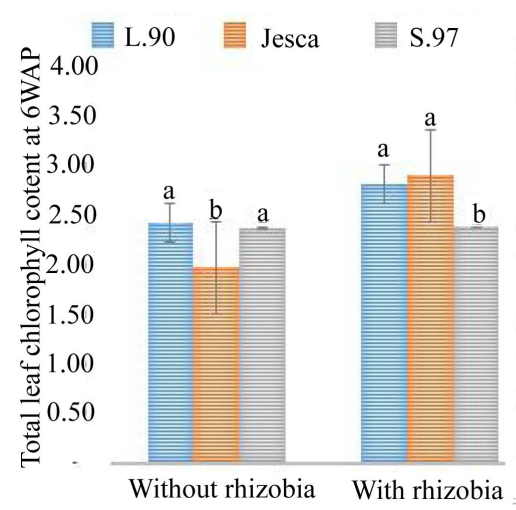

(a)

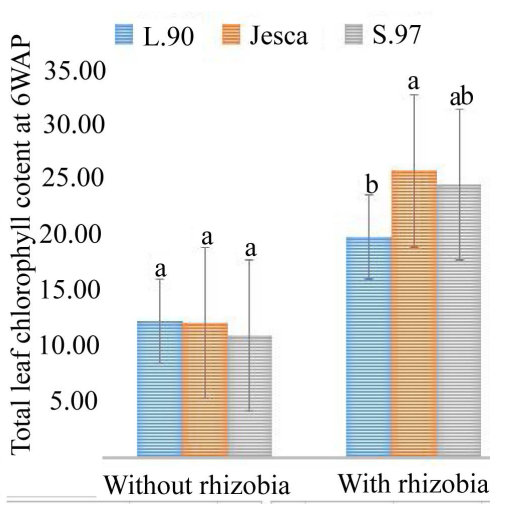

(b)

Figure 6. Interactive effect of rhizobia and varieties on total leaf chlorophyll content of three bush bean varieties recorded at 6 WAP in field and glass house experiment 2014. L.90 = Lyamungo 1990; S.97 = Selian 1997. Bars followed by dissimilar letters are significantly different at $\mathrm{p}=0.05$ according to Fischer least significance difference. (a) Field experiment; (b) Glass house experiment.

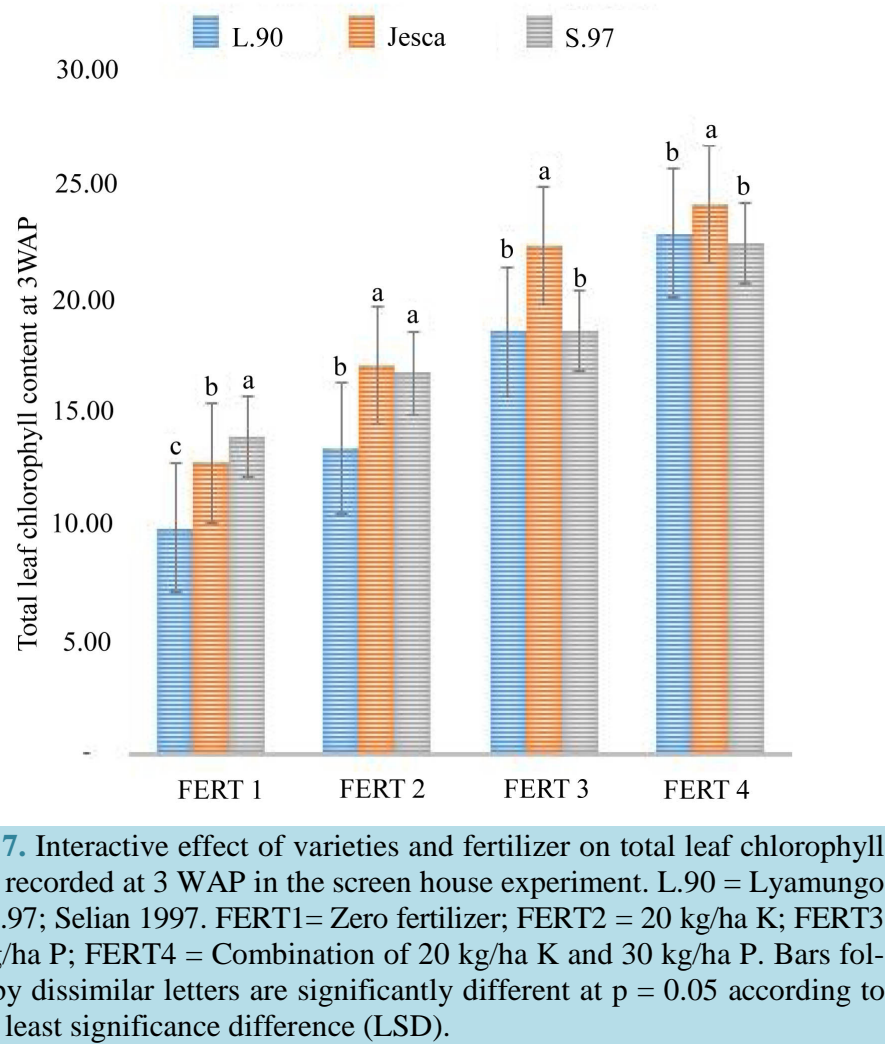

lowed by phosphorus and potassium. Better results were recorded in plots supplied with the both rhizobial inoculant, and combination of phosphorus and potassium at $30 \mathrm{~kg} / \mathrm{ha}$ and $20 \mathrm{~kg} / \mathrm{ha}$ respectively. Significant interactive effects exhibited by inoculating the soil with Rhizobium, and supplementing it with phosphorus and potassium suggest the need of this technology in the study area.

\section{Acknowledgements}

Special thanks to the Nelson Mandela African Institution of Science and Technology (NMAIST) and the Com- 


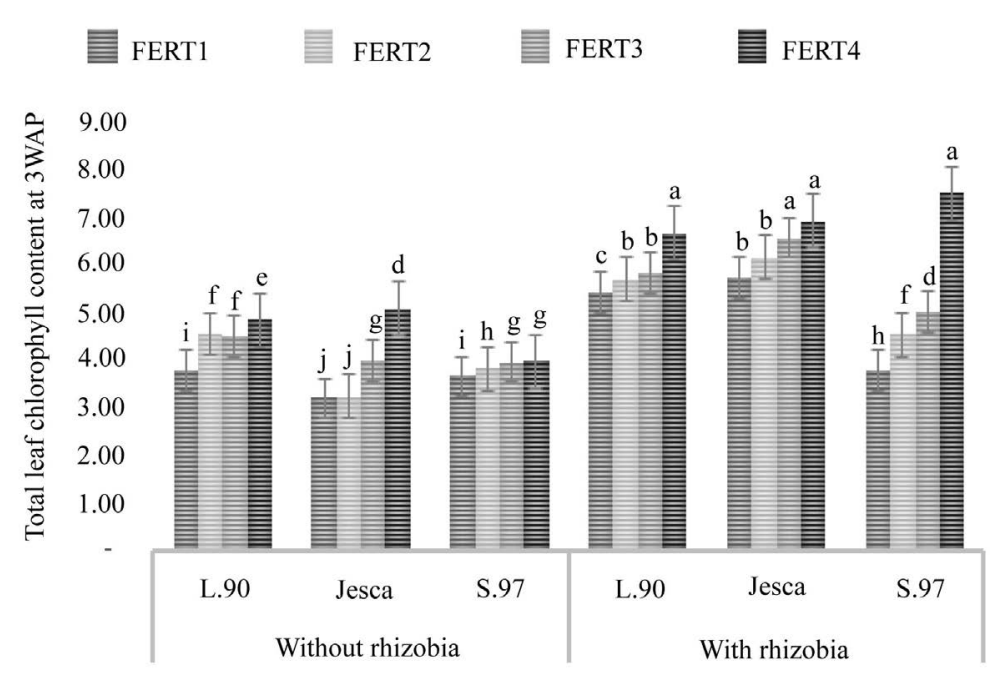

Figure 8. Interactive effect of rhizobia inoculation, fertilizer and varieties on the total leaf Chlorophyll content recorded in the field experiment at 3 WAP 2014. L.90 = Lyamungo 90; S.97 = Selian 97FERT1 = Zero fertilizer; FERT2 $=20 \mathrm{~kg} / \mathrm{ha} \mathrm{K}$; FERT3 = $30 \mathrm{~kg} / \mathrm{ha}$ P; FERT4 = Combination of $20 \mathrm{~kg} / \mathrm{ha} \mathrm{K}$ and $30 \mathrm{~kg} / \mathrm{ha}$ P. Bars followed by dissimilar letters are significantly different at $\mathrm{p}$ $=0.05$ according to Fischer least significance difference (LSD).

mission for Science and Technology (COSTECH) of Tanzania that supported this study and Tanzania Coffee Research Institute (TaCRI) for providing study site.

\section{References}

[1] Graham, P. and Vance, C. (2000) Nitrogen Fixation in Perspective: An Overview of Research and Extension Needs. Field Crops Research, 65, 93-106. http://dx.doi.org/10.1016/S0378-4290(99)00080-5

[2] Bambara, S. and Ndakidemi, P.A. (2010) The Potential Roles of Lime and Molybdenum on the Growth, Nitrogen Fixation and Assimilation of Metabolites in Nodulated Legume: A Special Reference to Phaseolus vulgaris L. African Journal of Biotechnology, 9, 2482-2489.

[3] Wortman, C., Kirkby, R., Eledu, C. and Allen, D. (1998) Atlas of Common Bean (Phaseolus vulgaris L.) Production in Africa (CIAT Publication No. 297). International Center for Tropical Agriculture, Cali.

[4] Morad, M., Sara, S., Alireza, E., Reza, C.M. and Mohammad, D. (2013) Effects of Seed Inoculation by Rhizobium Strains on Yield and Yield Components in Common Bean Cultivars (Phaseolus vulgaris L.). International Journal of Biosciences (IJB), 3, 134-141. http://dx.doi.org/10.12692/ijb/3.3.134-141

[5] Tairo, E.V. and Ndakidemi, P.A. (2013) Bradyrhizobium Japonicum Inoculation and Phosphorus Supplementation on Growth and Chlorophyll Accumulation in Soybean (Glycine max L.). American Journal of Plant Sciences, 4, 2281. http://dx.doi.org/10.4236/ajps.2013.412282

[6] Vessey, J.K. (2004) Benefits of Inoculating Legume Crops with Rhizobia in the Northern Great Plains. Crop Management. (Online)

[7] Hardarson, G. (1993) Methods for Enhancing Symbiotic Nitrogen Fixation. In: Bliss, F.A. and Hardarson, G., Eds., Enhancement of Biological Nitrogen Fixation of Common Bean in Latin America, Springer, Dordrecht, 1-17.

[8] Dakora, F. and Keya, S. (1997) Contribution of Legume Nitrogen Fixation to Sustainable Agriculture in Sub-Saharan Africa. Soil Biology and Biochemistry, 29, 809-817. http://dx.doi.org/10.1016/S0038-0717(96)00225-8

[9] Vargas, M.A., Mendes, I.C. and Hungria, M. (2000) Response of Field-Grown Bean (Phaseolus vulgaris L.) to Rhizobium Inoculation and Nitrogen Fertilization in Two Cerrados Soils. Biology and Fertility of Soils, 32, 228-233. http://dx.doi.org/10.1007/s003740000240

[10] Bambara, S. and Ndakidemi, P.A. (2009) Effect of Rhizobium Lime and Molebdenum on Photosynthesis and Chlorophyll Content of Phaseolus vulgaris L. African Journal of Microbiology Research, 3, 791-798.

[11] Bambara, S. and Ndakidemi, P.A. (2010) Effects of Rhizobium Innoculation, Lime and Molybdenum on Nitrogen Fixation of Nodulated Phaseolus vulgaris L. African Journal of Microbiology Research, 4, 682-696.

[12] Nyoki, D. and Ndakidemi, P.A. (2014) Effects of Phosphorus and Bradyrhizobium japonicum on Growth and Chloro- 
phyll Content of Cowpea (Vigna unguiculata (L) Walp). American Journal of Experimental Agriculture, 4, 1120-1136. http://dx.doi.org/10.9734/AJEA/2014/6736

[13] Namvar, A., Sharifi, R.S., Sedghi, M., Zakaria, R.A., Khandan, T. and Eskandarpour, B. (2011) Study on the Effects of Organic and Inorganic Nitrogen Fertilizer on Yield, Yield Components, and Nodulation State of Chickpea (Cicer arietinum L.). Communications in Soil Science and Plant Analysis, 42, 1097-1109. http://dx.doi.org/10.1080/00103624.2011.562587

[14] Malik, M.A., Cheema, M.A., Khan, H.Z. and Wahid, M.A. (2006) Growth and Yield Response of Soybean (Glycine max L.) to Seed Inoculation and Varying Phosphorus Levels. Journal of Agricultural Research, 44, 47-53.

[15] CIAT (Centro Internacional de Agricultura Tropical) (1989) Bean Production Problems in the Tropics. In: Schwartz, H.F. and Pastor-Corrales, M.A., Eds., 2nd Edition, Cali, 726 p.

[16] Uchida, R. (2000) Essential Nutrients for Plant Growth: Nutrient Functions and Deficiency Symptoms. In: Silva, J.A. and Uchida, R., Eds., Plant Nutrient Management in Hawaii's Soils, Approaches for Tropical and Subtropical Agriculture, College of Tropical Agriculture and Human Resources, University of Hawaii at Manoa, Honolulu, 31-55.

[17] Khurana, A. and Sharma, P. (2000) Effect of Dual Inoculation of Phosphate Solubilizing Bacteria, Bradyrhizobium sp. (cicer) and Phosphorus on Nitrogen Fixation and Yield of Chickpea. Indian Journal of Pulses Research, 13, 66-67.

[18] Shahid, M.Q., Saleem, M.F., Khan, H.Z. and Anjum, S.A. (2009) Performance of Soybean (Glycine max L.) under Different Phosphorus Levels and Inoculation. Pakistan Journal of Agricultural Sciences, 46, 237-241.

[19] Rubio, V., Linhares, F., Solano, R., Martín, A.C., Iglesias, J., Leyva, A., et al. (2001) A Conserved MYB Transcription Factor Involved in Phosphate Starvation Signaling both in Vascular Plants and in Unicellular Algae. Genes \& Development, 15, 2122-2133. http://dx.doi.org/10.1101/gad.204401

[20] Ndakidemi, P. and Semoka, J. (2006) Soil Fertility Survey in Western Usambara Mountains, Northern Tanzania. Pedosphere, 16, 237-244. http://dx.doi.org/10.1016/S1002-0160(06)60049-0

[21] Araújo, A.P., Teixeira, M.G. and Almeida, D.L.D. (2000) Growth and Yield of Common Bean Cultivars at Two Soil Phosphorus Levels under Biological Nitrogen Fixation. Pesquisa Agropecuária Brasileira, 35, 809-817. http://dx.doi.org/10.1590/S0100-204X2000000400019

[22] Olivera, M., Tejera, N., Iribarne, C., Ocana, A. and Lluch, C. (2004) Growth, Nitrogen Fixation and Ammonium Assimilation in Common Bean (Phaseolus vulgaris): Effect of Phosphorus. Physiologia Plantarum, 121, 498-505. http://dx.doi.org/10.1111/j.0031-9317.2004.00355.x

[23] Ndakidemi, P., Dakora, F., Nkonya, E., Ringo, D. and Mansoor, H. (2006) Yield and Economic Benefits of Common Bean (Phaseolus vulgaris) and Soybean (Glycine max) Inoculation in Northern Tanzania. Animal Production Science, 46, 571-577. http://dx.doi.org/10.1071/EA03157

[24] Kumar, R. and Chandra, R. (2008) Influence of PGPR and PSB on Rhizobium leguminosarum bv. Viciae Strain Competition and Symbiotic Performance in Lentil. World Journal of Agricultural Sciences, 4, 297-301.

[25] Marschner, H., Kirkby, E. and Cakmak, I. (1996) Effect of Mineral Nutritional Status on Shoot-Root Partitioning of Photoassimilates and Cycling of Mineral Nutrients. Journal of Experimental Botany, 47, 1255-1263. http://dx.doi.org/10.1093/jxb/47.Special_Issue.1255

[26] Stromberg, K. (1960) Probabilities on a Compact Group. Transactions of the American Mathematical Society, 94, 295309. http://dx.doi.org/10.1090/S0002-9947-1960-0114874-4

[27] Fletcher, R., Kallidumbil, V. and Bhardwaj, S. (1982) Effects of Fusicoccin on Fresh Weight and Chlorophyll Levels in Cucumber Cotyledons. Plant and Cell Physiology, 23, 717-719.

[28] Maples, R., Thompson, W. and Varvil, J. (1988) Potassium Deficiency in Cotton Takes on a New Look. Better Crops with Plant Food, 73, 6-9.

[29] Zhao, D., Oosterhuis, D. and Bednarz, C. (2001) Influence of Potassium Deficiency on Photosynthesis, Chlorophyll Content, and Chloroplast Ultrastructure of Cotton Plants. Photosynthetica, 39, 103-109. http://dx.doi.org/10.1023/A:1012404204910

[30] Collins, M. and Duke, S.H. (1981) Influence of Potassium-Fertilization Rate and Form on Photosynthesis and $\mathrm{N}_{2}$ Fixation of Alfalfa. Crop Science, 21, 481-485. http://dx.doi.org/10.2135/cropsci1981.0011183X002100040001x

[31] Li, M., Dac, P., Luo, C. and Zhang, S. (1989) Interaction Effect of K and B on Rapeseed Yield and Nutrient Status in Rape Plants. Journal of Soil Science, 32, 212-216.

[32] Sharma, K., Kuhad, M. and Nandwal, A. (1992) Possible Role of Potassium in Drought Tolerance in Brassica. Journal of Potassium Research, 8, 320-327.

[33] Singh, N. and Kataria, N. (2012) Role of Potassium Fertilizer on Nitrogen Fixation in Chickpea (Cicer arietinum L.) under Quantified Water Stress. Journal of Agricultural Technology, 8, 377-392.

[34] Newton, W.E. and Burgess, B.K. (1983) Nitrogen Fixation: Its Scope and Importance. In: Nitrogen Fixation, Springer, 
Berlin, 1-19.

[35] O’Hara, G.W. (1998) The Role of Nitrogen Fixation in Crop Production. Journal of Crop Production, 1, 115-138.

[36] Bambara, S. and Ndakidemi, P.A. (2010) Phaseolus vulgaris Response to Rhizobium Inoculation, Lime and Molybdenum in Selected Low pH Soil in Western Cape, South Africa. African Journal of Agricultural Research, 5, 1804-1811.

[37] Ravikumar, R. (2012) Growth Effects of Rhizobium Inoculation in Some Legume Plants. International Journal of Current Science, 1, 1-6.

[38] Bambara, S. and Ndakidemi, P.A. (2009) Effects of Rhizobium Inoculation, Lime and Molybdenum on Photosynthesis and Chlorophyll Content of Phaseolus vulgaris L. African Journal of Microbiology Research, 3, 791-798.

[39] Mairura, F., Mugendi, D., Mwanje, J., Ramisch, J., Mbugua, P. and Chianu, J. (2007) Integrating Scientific and Farmers’ Evaluation of Soil Quality Indicators in Central Kenya. Geoderma, 139, 134-143. http://dx.doi.org/10.1016/j.geoderma.2007.01.019

[40] Berg Jr., R.K. and Lynd, J. (1985) Soil Fertility Effects on Growth, Yield, Nodulation and Nitrogenase Activity of Austrian Winter Pea. Journal of Plant Nutrition, 8, 131-145. http://dx.doi.org/10.1080/01904168509363330

[41] Pacovsky, R. (1988) Influence of Inoculation with Azospirillum brasilense and Glomus fasciculatum on Sorghum Nutrition. Plant and Soil, 110, 283-287. http://dx.doi.org/10.1007/BF02226809

[42] Kasturikrishna, S. and Ahlawat, I. (1999) Growth and Yield Response of Pea (Pisum sativum) to Moisture Stress, Phosphorus, Sulphur and Zinc Fertilizers. Indian Journal of Agronomy, 44, 588-596.

[43] Akhtar, N., Amjad, M. and Anjum, M.A. (2003) Growth and Yield Response of Pea (Pisum sativum I.) Crop to Phosphorus and Potassium Application. Pakistan Journal of Agricultural Sciences, 40, 217-222.

[44] Slaton, N.A., DeLong, R., Golden, B.R. and Mozaffari, M. (2007) Full-Season, Irrigated Soybean Response to Potassium Fertilization in Arkansas. Better Crops, 91, 28-30.

[45] Johnston, A.M., Clayton, G.W. and Miller, P.R. (2007) Symposium Papers. Agronomy Journal, 99, 1682-1683.

[46] Kurdali, F., Al-Ain, F. and Al-Shamma, M. (2002) Nodulation, Dry Matter Production, and $\mathrm{N}_{2}$ Fixation by Fababean and Chickpea as Affected by Soil Moisture and Potassium Fertilizer. Journal of Plant Nutrition, 25, 355-368. http://dx.doi.org/10.1081/PLN-100108841

[47] Kanaujia, S., Narayan, R. and Narayan, S. (1999) Effect of Phosphorus and Potassium on Growth, Yield and Quality of French Bean (Phaseolus vulgaris L.) cv. Contender. Vegetable Science, 26, 91-92.

[48] Chaudhary, M.I. and Fujita, K. (1998) Comparison of Phosphorus Deficiency Effects on the Growth Parameters of Mashbean, Mungbean, and Soybean. Soil Science and Plant Nutrition, 44, 19-30. http://dx.doi.org/10.1080/00380768.1998.10414423

[49] Amijee, F. and Giller, K.E. (1998) Environmental Constraints to Nodulation and Nitrogen Fixation of Phaseolus vulgaris L. in Tanzania. A Survey of Soil Fertility, Root Nodulation and Multi-Locational Responses to Rhizobium Inoculation. African Crop Science Journal, 6, 159-170. http://dx.doi.org/10.4314/acsj.v6i2.27812

[50] Smithson, J.B., Edje, O.T. and Giller, K.E. (1993) Diagnosis and Correction of Soil Nutrient Problems of Common Bean (Phaseolus vulgaris) in the Usambara Mountains of Tanzania. The Journal of Agricultural Science, 120, $233-240$. http://dx.doi.org/10.1017/S0021859600074281

[51] Abdelgani, M., Elsheikh, E. and Mukhtar, N. (1999) The Effect of Rhizobium Inoculation and Chemical Fertilization on Seed Quality of Fenugreek. Food Chemistry, 64, 289-293. http://dx.doi.org/10.1016/S0308-8146(98)00098-3

[52] Chen, J. (2006) The Combined Use of Chemical and Organic Fertilizers and/or Biofertilizer for Crop Growth and Soil Fertility. In: International Workshop on Sustained Management of the Soil-Rhizosphere System for Efficient Crop Production and Fertilizer Use, Thailand, 16-20 October, 2006, 20.

[53] Patra, R., Pant, L. and Pradhan, K. (2012) Response of Soybean to Inoculation with Rhizobial Strains: Effect on Growth, Yield, N Uptake and Soil N Status. World Journal of Agricultural Sciences, 8, 51-54.

[54] Nyoki, D. and Ndakidemi, P.A. (2014) Effects of Bradyrhizobium japonicum Inoculation and Supplementation with Phosphorus on Macronutrients Uptake in Cowpea (Vigna unguiculata (L.) Walp). American Journal of Plant Sciences, 5, 442-451. http://dx.doi.org/10.4236/ajps.2014.54058

[55] Menaria, B., Pushpendra, S., Nagar, R. and Singh, P. (2003) Effect of Nutrients and Microbial Inoculants on Growth and Yield of Soybean [Glycine max (L.) Merril]. Journal of Soil and Crops. Soils and Crops, 13, 14-17.

[56] Popescu, A. (1998) Contributions and Limitations to Symbiotic Nitrogen Fixation in Common Bean (Phaseolus vulgaris L.) in Romania. In: Molecular Microbial Ecology of the Soil, Springer, Berlin, 117-125. 
Scientific Research Publishing (SCIRP) is one of the largest Open Access journal publishers. It is currently publishing more than 200 open access, online, peer-reviewed journals covering a wide range of academic disciplines. SCIRP serves the worldwide academic communities and contributes to the progress and application of science with its publication.

Other selected journals from SCIRP are listed as below. Submit your manuscript to us via either submit@scirp.org or Online Submission Portal.
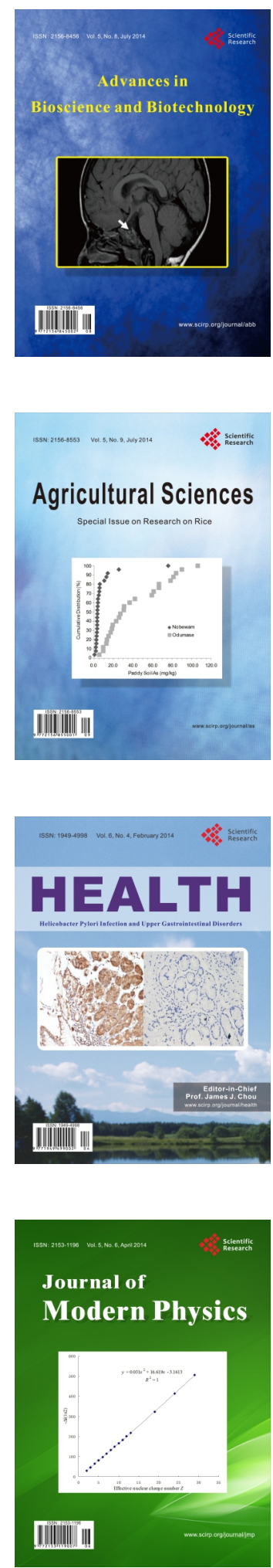
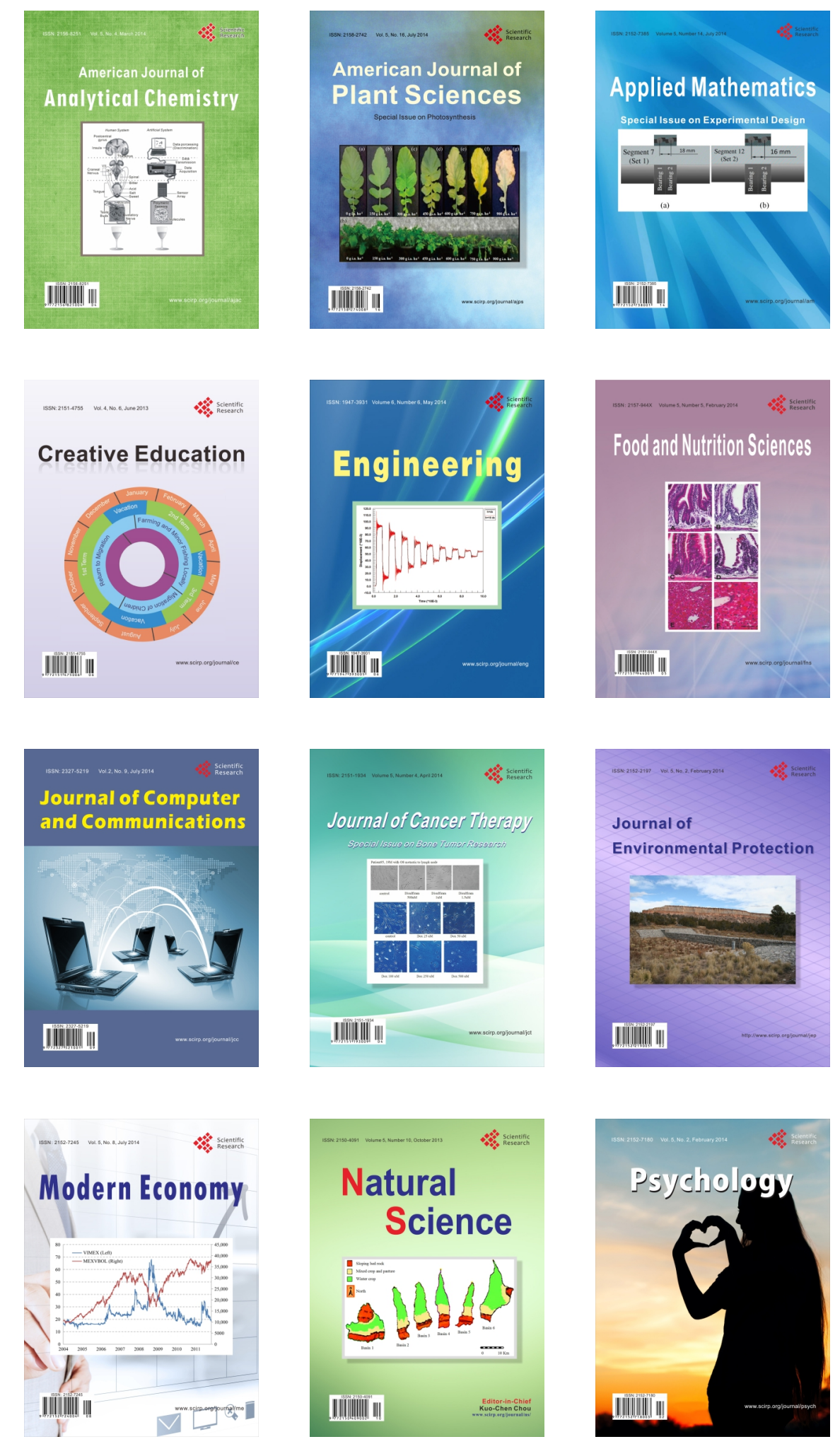